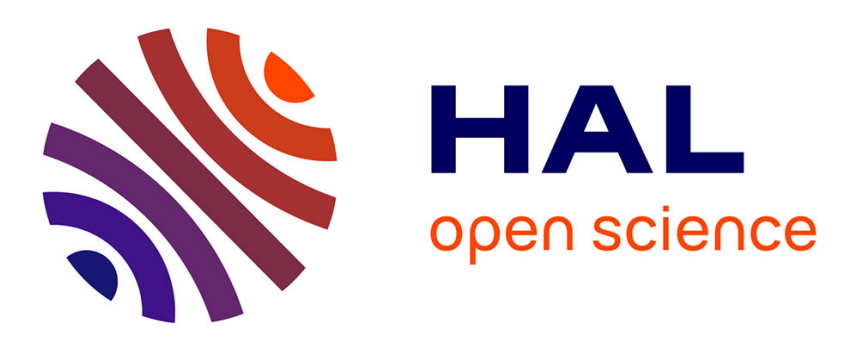

\title{
The CAQ network in France: 15 years of brainstorming and cooperative work to connect forest resources and wood quality through modelling approaches and simulation software
}

Auclair, Nepveu

\section{To cite this version:}

Auclair, Nepveu. The CAQ network in France: 15 years of brainstorming and cooperative work to connect forest resources and wood quality through modelling approaches and simulation software. Annals of Forest Science, 2012, 69 (2), pp.119-123. 10.1007/s13595-012-0185-4 . hal-00930836

\section{HAL Id: hal-00930836 https://hal.science/hal-00930836}

Submitted on 1 Jan 2012

HAL is a multi-disciplinary open access archive for the deposit and dissemination of scientific research documents, whether they are published or not. The documents may come from teaching and research institutions in France or abroad, or from public or private research centers.
L'archive ouverte pluridisciplinaire HAL, est destinée au dépôt et à la diffusion de documents scientifiques de niveau recherche, publiés ou non, émanant des établissements d'enseignement et de recherche français ou étrangers, des laboratoires publics ou privés. 


\title{
The CAQ network in France: 15 years of brainstorming and cooperative work to connect forest resources and wood quality through modelling approaches and simulation software
}

\author{
Daniel Auclair • Gérard Nepveu
}

Received: 18 January 2012 / Accepted: 20 January 2012/Published online: 23 February 2012

(C) INRA / Springer-Verlag France 2012

\section{Introduction to the CAQ network}

This special issue on "Tree growth and forest production modelling, at different spatio-temporal scales, for various ecosystem processes, functions and services" was initiated during the 13th annual meeting of the CAQ network, held in Grenoble (France) during 2010. The history of this network goes back to the early 1970 s, when a small group of dendrometricians from France, Belgium and Switzerland met annually (among others J.H. Bartet, J. Bouchon, M. Buffet, F. Cailliez, N. Decourt, P. Duplat, B. Lemoine, J. Rondeux, J.P. Schütz). Amicable scientific discussions focused around forest statistics, tree growth and stand dynamics and simulation, and were an opportunity for junior scientists to meet their elders. For reasons it would be politically incorrect to reveal in detail here, the group was abruptly dissolved during 1985.

It took more than 10 years before the "CAQ Project" was submitted for funding in 1997. The project was "an attempt to include ecophysiological considerations into tree growth and wood quality models based on statistical and empirical approaches" that were developed at that time. The name "CAQ" was initiated from the combination of growth

\footnotetext{
D. Auclair $(\bowtie)$

INRA; UMR AMAP (Botanique et Bioinformatique

de l'Architecture des Plantes),

Montpellier 34398, France

e-mail: auclair@cirad.fr

G. Nepveu

INRA; UMR LERFoB

(Laboratoire d'Étude des Ressources Forêt-Bois),

Champenoux 54280, France

e-mail: nepveu@nancy.inra.fr
}

(croissance), breeding (amélioration) and wood quality (qualité $d u$ bois). The initial idea was to gather scientists from INRA and other French research and development institutes involved in tree growth, breeding and wood quality, as well as ecophysiologists, around a central topic. The initial CAQ network involved scientists representing a large spectrum of fields of research such as forest ecophysiology, tree growth and yield modelling, wood quality, tree breeding and genetics as well as mathematics and informatics (Nepveu et al. 1997). Although the funding of the project was far below our expectations, a financial support was provided by the French Ministry of Agriculture in the frame of a pluri-annual cooperative programme entitled "Modelling and software integration: growth, branchiness, wood quality - decision support for silviculture and wood use of several French forest species". From then on, researchers and developers involved in the programme met annually during 1-2 days. Although the funding ran out at the issue of the 5-year programme (Auclair 2002), the CAQ meetings continued on an annual basis and became the focus point of scientists and engineers from various countries involved in applied and basic research projects and wishing to exchange their experience on their often contrasted work, but animated by the same "CAQ spirit". The CAQ group became the "network of French-speaking researchers and developers involved in forest and wood modelling", addressing: (1) the development of elementary models (growth, branchiness, wood density...), (2) their integration in decision tools (simulators) and (3) the use of these simulators to answer more or less complex questions. The latter objective explains the close cooperation with the community developing the CAPSIS platform (Dufour-Kowalski et al. 2012).

The initial objectives of CAQ have extended with the evolving socio-economic context, and now address broader topics, such as: (1) more complex systems (uneven-aged and 
mixed stands, global change), (2) new modelling issues (landscape, $\mathrm{CO}_{2}$ balance throughout the forest wood chain, employment, income, ecosystem sustainability, biodiversity...), (3) multicriteria simulation and optimization and (4) risk considerations (fire, storm, fluctuating wood price, changes in wood use...). The CAQ mailing list now comprises 314 scientists, professors, engineers, extension agents and ministry representatives, from eight countries (mostly French). Annual meetings gather from 30 to 50 persons for an average of 20 oral presentations, which are all available on the website http://www4. inra.fr/efpa/Animation/Reseaux-d-animation\#CAQ. In addition to the French-speaking community, many CAQ members are also actively involved in international groups, in particular the IUFRO 5.01.04 Working Party "Wood Quality Modelling", coordinated by Gérard Nepveu from 1991 to 2005, who organized during this time five workshops on the topic "Connection between Forest Resources and Wood Quality: Modelling Approaches and Simulation Software".

\section{Fifteen papers illustrating the scientific production of the CAQ network}

The objective of this thematic issue of Annals of Forest Science is not to synthesize the results of " 15 years of brainstorming", nor to list the scientific papers produced or to compute a bibliometric index or the number of lines of computer code written. It neither is to collate the experimental and observation areas established and monitored, the scientific projects written, submitted, and eventually accepted, following the discussions which took place throughout the CAQ annual sessions. The papers presented in this thematic issue are a sample of the latest results obtained by members of the network. Not all ecosystem processes, functions and services addressed by CAQ are described here, but the selection of papers comprises different scales or "organization levels" ranging from tree branch to region, and addresses issues ranging from applied research to theoretical developments.

The first three papers address the branch scale. Courbet et al. (2012) describe a model accounting for branch diameter distribution among growth units of Atlantic cedar (Cedrus atlantica), showing the influence of acrotony. Morisset et al. (2012) show that the frequency of epicormic shoots in oak (Quercus petraea and Quercus robur) is strongly dependent on the individual tree, suggesting that silvicultural management should favour the individuals free of epicormics and concentrate on felling those which are prone to their development. De Reffye et al. (2012) propose a theoretical model of the dynamics of individual shoots based on the renewal theory, to account for stochastic aspects of phytomer production resulting from meristem extension and rest periods, and mortality.
The two following papers address the tree crown level. Letort et al. (2012) investigate the dynamics of trophic competition within a Cecropia sciadophylla crown, which they model according to local environmental conditions. Da Silva et al. (2012) analyse the opportunity to simplify the description of tree crowns for modelling light transmission; they show that using a geometric shape can prove acceptable, whereas simple allometric relations can seriously reduce the accuracy.

Two papers address the issue of self-thinning in different types of stands. Rivoire and Le Moguédec (2012) use a generalized modelling approach to extend the relation initially calibrated for homogeneous stands to mixed species and mixed size forests, they show that it is possible to adjust a theoretical relation for oak ( $Q$. petraea and $Q$. robur), beech (Fagus sylvatica), and spruce (Picea abies) in mixed stands. Charru et al. (2012) analyse data from the French National Forest Inventory and show that the shape of selfthinning relationships exhibits important variations between species; they also point out the high influence of ontogeny on self-tolerance.

Five papers address the stand level. Dufour-Kowalski et al. (2012) describe the CAPSIS framework, which is used extensively by many CAQ members, and also by other forest modellers, for implementing, integrating, simulating and comparing forest models, by sharing the software developments. Lafond et al. (2012) propose an algorithm to reconstruct past harvesting diameter distributions in selection systems, for implementation in growth simulators when insufficient information is available. Le Moguédec and Dhôte (2012) describe in detail the distance-independent tree-centred Fagacées growth and yield model for sessile oak ( $Q$. petraea) and beech (F. sylvatica), which first computes growth at the stand level and in a second stage allocates growth between the individual trees. Feng et al. (2012) combine an individual tree architectural model for black pine (Pinus nigra nigra) with an empirical stand model, to simulate individual tree structure development according to silvicultural scenarios, with an application to whole stand visualization. Fortin and Langevin (2012) analyse the importance of implementing stochastic processes in stand models and show that deterministic simulations can result in biased predictions.

The last three papers address wider areas. Dreyfus (2012) uses an individual-based stand dynamics model which simulates recruitment, growth and mortality, which he implements at the landscape level by considering the spatial arrangement of stands and species (beech-F. sylvatica, fir-Abies alba, pine-P. nigra, Pinus sylvestris and Pinus uncinata), resulting in a decision support tool accounting for colonization and forest maturation. Wernsdörfer et al. (2012), using a resource projection model based on French National Forest Inventory data at the regional level, show the impact of region, species 
composition and stand structure on resource predictions, in particular on estimation of the recruitment process. Barbier et al. (2012) develop a theoretical framework for analysing large-scale forest structure from remote sensing data, with promising applications for assessing forest structure, dynamics, matter and energy budgets, and forest degradation.

\section{Some ideas about the future of the CAQ network}

The 15th annual CAQ meeting, due to take place on 2-4 April 2012 in Nogent-sur-Vernisson (Loiret, France), is an opportunity to think about the prospects, particularly as the two co-coordinators of the network will withdraw to let a younger generation take over. Our aim here is not to dictate any future action - we leave this to our successors - but to point out a few challenges ahead of us, concerning scientific and management issues.

The statement of Box and Draper (1987) that "all models are false, but some are useful" is often cited by modellers, although sometimes disputed. Without entering into such a controversy, it is important to keep in mind the objectives of the model(s) we develop, which range from the improvement and organization of scientific knowledge to decision support systems. Recent progress in scientific knowledge poses particular challenges.

Scientific knowledge on plant physiology is making tremendous progress, but processes at the cellular level still require considerable attention, and their integration into higher levels of organization - and complexity - is a serious challenge. A real integration of existing - and futureknowledge on tree architecture processes into "functionalarchitectural models", correctly addressing population- and community-level questions, is another important issue. The increase in computer capacity and the development of information technology in the past decades offer many new possibilities, such as the management of large databases ("data cloud" management), large-scale clusters, massive computation ("cloud computing") and HPC ("high performance computing"), the development of web services and the widespread use of open-source software, or the implementation of "in silico" experiments permitting numerous replications. Bayesian methods have resurged with the development of Monte Carlo techniques and offer new statistical applications in connection with decision theory and machine learning. And in return, as stated by Cohen (2004), future biological challenges could stimulate major innovations in mathematics, for example in modelling multilevel systems, or in further - and better - addressing plantenvironment interactions, plant-insect or more largely plantanimal (including humans) interactions, and more generally in the domain of "complex systems".
New technologies offer tremendous opportunities to improve and integrate "basic" knowledge, to simulate increasingly complex phenomena, to store masses of data and results... however, this acceleration of technological performance and the ease of use of complex and powerful technology open the way to the temptation of entering - and remaining within-virtual reality, developing large-scale high-tech virtual experiments and producing masses of virtual data. We are not always able to analyse in a satisfactory manner the widespread accumulation of data (either coming from the real world or from virtual experiments), to select the really pertinent data and to reflect upon the knowledge acquired through these tools, which must remain tools and not become an objective per se.

In his keynote presentation of "LandMod2010" International Conference on Integrative Landscape Modelling, one of us emphasized that "In the past 20 years, and even more so since the beginning of the 21 st century, a large number of models destined to forest and natural ecosystem management have been developed, with multicriteria or multiscale approaches. With improvements in computer capacity, mathematical developments on the issue of complexity, multicriteria optimisation and multiscale modelling methods, there is now a great opportunity for developing robust decision support systems for long- and short-term planning" (Auclair 2010). In the twenty-first century even more than previously, managers and decision makers are increasingly facing new challenges, in relation to natural and/or anthropogenic changes. Climate change is one important element which profoundly modifies the way forest planning must be envisaged: forest growth will be impacted, but also future geographical distribution of species. Important changes in land use are also impacting large forest areas, and recent trends lead forest managers to base their decisions on increasingly global organization levels, moving upwards from parcel and forest estate to landscape. In this changing and uncertain environment, which includes varying regulatory and economic conditions, forest and natural ecosystem managers are increasingly requested to address simultaneously a large variety of ecosystem services (MEA 2005). This requires advanced decision support tools, such as expert and knowledge-based systems, multicriteria techniques as well as communication and visualization tools.

Carbon management (sequestration, substitution, adaptation) is a sensitive political issue. It remains unclear what is the optimum silvicultural system to maximise carbon sequestration (notwithstanding other ecosystem services). The use of forest products for building or for energy production as a substitute for fossil materials faces the powerful energy and building industrial lobbies. Despite a common belief that plant growth can be expected to increase with increasing $\mathrm{CO}_{2}$, there is evidence that carbon is not the limiting factor for plant growth (Díaz et al. 1993), and if plants or ecosystems do not 
adapt to global change, managers must anticipate and adapt their management systems. In addition to high temperatures and $\mathrm{CO}_{2}$ content, rare climatic events such as severe droughts and windstorms are expected to become more common in future, as well as wildfires, erosion and landslides, and it is important to anticipate risks in forest management.

Biodiversity has become an increasing concern worldwide, particularly since the Rio "Earth Summit" in 1992. Forest and natural ecosystem management addresses biodiversity and its various components: genes, species and ecosystems. Many important issues must be considered in this respect, such as pollination, seed dispersal (including GMO dispersal) and invasive and/or alien species.

Forest management and ecological engineering most often address one or two objectives, rarely more, and very rarely the interactions between these objectives. Managers generally address the considered objective(s) at the most appropriate organization level(s), but rarely account for spatial dependency. Although there is a trend for forest management to address multiple objectives, it is becoming necessary to address the entire spectrum from plant through forest stand to region for a large number of objectives to be considered.

We are convinced that the progress, the vitality, the originality and the social utility of the CAQ network, particularly since it has been reinforced by a close cooperation with the developers in charge of the CAPSIS platform, are based on the fact that it has endeavoured to unite intimately the production of "good science" and the development of models produced thanks to this "good science", resulting in multicriteria and multiscale simulation software which help the stakeholders of the forest wood chain (including scientists) to address the increasingly complex questions they are facing, in connection with the other needs of society. This conjunction of the two pillars, model delivery and simulation software production, is a key to the future successes of CAQ.

Acknowledgements The CAQ network was initiated thanks to funds provided by the French Ministry of Agriculture. Thanks are also due to the INRA EFPA division for its intellectual support and recently for its (small but nonetheless significant) financial contribution. We wish to thank Yves Dumont for the fruitful discussions and constructive editing of an earlier version of this introductory paper.

\section{References}

Auclair D (2002) Modélisation et intégration logicielle : croissance, branchaison, qualité des bois. Aide à la décision pour la sylviculture et l'utilisation du bois des essences forestières françaises. Convention MAPA-DERF/INRA $n^{\circ}$ 61.45.47/01. INRA, Montpellier

Auclair D (2010) Forest and natural ecosystem managers in the landscape-multiscale modelling, challenges and opportunities. In:
Fabre JC, Jaeger M, Louchart X, Muller JP (eds) LANDMOD2010: International Conference on Integrative Landscape Modelling-linking environmental, social and computer sciences. Symposcience. http://www.symposcience.org/exl-php/articles/ 626-article.htm

Barbier N, Couteron P, Gastellu-Etchegorry JP, Proisy C (2012) Linking canopy images to forest structural parameters: potential of a modeling framework. Ann For Sci 69. doi:10.1007/ s13595-011-0116-9

Box GEP, Draper NR (1987) Empirical model-building and response surfaces. Wiley, Oxford

Charru M, Seynave I, Morneau F, Rivoire M, Bontemps JD (2012) Significant differences and curvilinearity in the selfthinning relationships of 11 temperate tree species assessed from forest inventory data. Ann For Sci 69. doi:10.1007/s13595011-0149-0

Cohen JE (2004) Mathematics is biology's next microscope, only better; biology is mathematics' next physics, only better. PLoS Biol 2:2017-2023

Courbet F, Herve JC, Klein EK, Colin F (2012) Diameter and death of whorl and inter-whorl branches in Atlas cedar (Cedrus atlantica Manetti): a model accounting for acrotony. Ann For Sci 69. doi:10.1007/s13595-011-0156-1

Da Silva D, Balandier P, Boudon F, Marquier A, Godin C (2012) Modeling of light transmission under heterogeneous forest canopy: an appraisal of the effect of the precision level of crown description. Ann For Sci 69. doi:10.1007/s13595-0110139-2

De Reffye P, Kang M, Hua J, Auclair D (2012) Stochastic modelling of tree annual shoot dynamics. Ann For Sci 69. doi:10.1007/s13595011-0151-6

Díaz S, Grime JP, Harris J, McPherson E (1993) Evidence of a feedback mechanism limiting plant response to elevated carbon dioxide. Nature 364:616-617

Dreyfus P (2012) Joint simulation of stand dynamics and landscape evolution using a tree-level model for mixed unevenaged forests. Ann For Sci 69. doi:10.1007/s13595-011-01632

Dufour-Kowalski S, Courbaud B, Dreyfus P, Meredieu C, De Coligny F (2012) Capsis: an open software framework and community for forest growth modelling. Ann For Sci 69. doi:10.1007/s13595011-0140-9

Feng L, De Reffye P, Dreyfus P, Auclair D (2012) Connecting an architectural plant model to a forest stand dynamics model application to Austrian black pine stand visualization. Ann For Sci 69. doi:10.1007/s13595-011-0144-5

Fortin M, Langevin L (2012) Stochastic or deterministic single-tree models: is there any difference in growth predictions? Ann For Sci 69. doi:10.1007/s13595-011-0112-0

Lafond V, Courbaud B, De Coligny F, Zingg A (2012) Reconstructing harvesting diameter distribution from aggregate data. Ann For Sci 69. doi:10.1007/s13595-011-0155-2

Le Moguédec G, Dhôte JF (2012) Fagacées: a tree-centered growth and yield model for sessile oak (Quercus petraea L.) and common beech (Fagus sylvatica L.). Ann For Sci 69. doi:10.1007/s13595011-0157-0

Letort V, Heuret P, Zalamea PC, De Reffye P, Nicolini E (2012) Analysing the effects of local environment on the source-sink balance of Cecropia sciadophylla: a methodological approach based on model inversion. Ann For Sci 69. doi:10.1007/s13595011-0131-x

MEA (2005) Millenium ecosystem assessment. Ecosystems and human well-being: synthesis. Island Press, Washington 
Morisset JB, Mothe F, Chopard B, François D, Fontaine F, Colin F (2012) Does past emergence of epicormic shoots control current composition of epicormic types? Ann For Sci 69. doi:10.1007/ s13595-011-0148-1

Nepveu G, Castéra P, Dreyfus P, Ranger J, Teissier du Cros E (1997) Projet de recherches coopératif CAQ: présentation générale; présentation des 19 contributions. Équipe de Recherches sur la Qualité des Bois, INRA, Nancy
Rivoire M, Le Moguédec G (2012) A generalized self-thinning relationship for multi-species and mixed-size forests. Ann For Sci 69 doi:10.1007/s13595-011-0158-Z

Wernsdörfer H, Colin A, Bontemps JD, Chevalier H, Pignard G, Caurla S, Leban JM, Hervé JC, Fournier M (2012) Large scale dynamics of a heterogeneous forest resource are jointly driven by geographically varying growth conditions, tree species composition and stand structure. Ann For Sci (in press) 